\title{
KUALITAS PELAYANAN TERHADAP KEPUASAN KONSUMEN PT PEGADAIAN OUTLET KEDATON DI BANDAR LAMPUNG SAAT PADEMI COVID-19
}

\author{
Ghina Erza Fortuna ${ }^{1}$, Dorothy Rouly Haratua Pandjaitan ${ }^{2}$ \\ Jurusan Manejemen, Fakultas Ekonomi dan Bisnis, Universitas Lampung \\ ghinaerza10@gmail.com ${ }^{1}$, dorothy.rouly81@gmail.com ${ }^{2 \ltimes}$
}

\begin{abstract}
ABSTRAK
Pandemi covid-19 berdampak secara luas pada berbagai sektor, diantaranya adalah sektor perekonomian. Pada sektor perekonomian dampaknya adalah pengangguran meningkat dan banyaknya pengusaha menutup gerai mereka karena adanya pandemi tersebut, dengan terjadinya hal seperti ini PT Pegadaian Outlet Kedaton membantu meringankan beban masyarakat dengan cara masyarakat tidak perlu menjual barangnya melainkan hanya menggadaikan barang yang masyarakat miliki.

Penelitian ini bertujuan untuk mengetahui pengaruh kualitas pelayanan terhadap kepuasan konsimen di PT Pegadaian Outlet Kedaton saat pandemi covid-19. Penelitian ini menggunakan metode non-probability sampling dengan tehnik purpose sampling, dengan sampel sebanyak 100 responden yang telah berkunjung serta melakukan transaksi di PT Pegadaian Outlet Kedaton selama pandemi covid-19. Hasil penelitian ini menunjukkan bahwa variabel bukti fisik, empati, keandalan, ketanggapan, dan jaminan berpengaruh positif secara signifikan terhadap kepuasan konsumen
\end{abstract}

Kata kunci: Kualitas Pelayanan, Kepuasan, Konsumen, Kinerja Karyawan, Pegadaian

\begin{abstract}
The covid-19 pandemic has had a broad impact on various sectors, such as the health, social, financial, and other sectors. In the economic sector, due to the pandemic, the number of unemployment increases, and many entrepreneurs close their outlets. Therefore, PT Pegadaian Outlet Kedaton is here to help ease the burden on the community by means that people don't have to sell their goods but only pawn the things they have.

This study aims to determine the effect of service quality on customer satisfaction at PT Pegadaian Outlet Kedaton during the covid-19 pandemic. This study uses a non-probability sampling method with a purposeful sampling technique, with a sample of 100 respondents who have visited and made transactions at PT Pegadaian Outlet Kedaton during the covid-19 pandemic. This study indicates that the variables tangible, empathy, reliability, responsiveness, and assurance, have a significant positive effect on customer satisfaction.
\end{abstract}

Keywords: Service Quality, Satisfaction, Consumer, Employee Performance, Pawnshop

\footnotetext{
${ }^{2} \gg$ Corresponding Author: Dorothy Rouly Haratua Pandjaitan (dorothy.rouly81@gmail.com)
} 


\section{PENDAHULUAN}

Lingkungan bisnis yang semakin kompetitif di era sekarang ini mengakibatkan kepuasan konsumen sangat penting karena perbedaan dalam produk dan layanan serta tingkat persaingan yang tinggi. Para konsumen memiliki pengetahuan dan pemahaman tentang suatu pelayanan yang akan berpengaruh dalam pemilihan suatu produk maupun jasa. Pelayanan yang berkualitas tinggi berperan penting dalam membentuk kepuasan konsumen, selain itu juga mampu menciptakan keuntungan bagi perusahaan, maka semakin tinggi kualitas pelayanan yang diberikan oleh perusahaan maka semakin tinggi pula kepuasan yang dirasakan oleh konsumen (Lasander, 2013). Perusahaan harus melakukan langkah-langkah dalam memberikan pelayanan yang optimal dalam mempertahankan daya minat seseorang konsumen, sehingga para konsumen mencapai kepuasan yang mereka butuhkan. Kepuasan konsumen khususnya di bidang pelayanan harus dilakukan dengan optimal dan berkualitas guna menarik minat para konsumen sehingga tercapainya kepuasaan konsumen, maka dari itu perusahaan dituntut untuk harus berusaha memahami kebutuhan dan keinginan para konsumen.

Pandemi yang terjadi pada saat ini disebut covid-19 berasal dari Kota Wuhan di China yang sudah menyebar ke berbagai negara di seluruh dunia, pada 11 Maret 2020 yang ditetapkan sebagai pandemi oleh WHO (World Health Organization). Pandemi adalah sebuah wabah yang telah menyebar ke beberapa negara atau benua, pandemi secara tidak langsung telah berdampak ke semua kalangan masyarakat secara umum, bukan hanya berdampak pada masalah kesehatan masyarakat tetapi ini adalah titik awal dari munculnya krisis ekonomi serta mempengaruhi sektor usaha mikro, kecil dan menengah. Indonesia melaporkan kasus pertama pada 2 Maret 2020, yang terlupakan tertular dari orang asing yang berkunjung ke Indonesia. Kasus di Indonesia pun terus bertambah, hingga tanggal 29 Maret 2020 telah terdapat 1.115 kasus dengan kematian mencapai 102 jiwa. Tingkat kematian Indonesia 9\%, termasuk angka kematian tertinggi. Pandemi ini terus meningkat dan sangat sulit dikendalikan, jika semakin banyak manusia yang terinfeksi maka akan lebih banyak orang yang mengalami ketakutan dikarenakan pandemi ini, bukan dari segi kesehatan saja tetapi pandemi telah merusak ekonomi dan juga sisi sosial masyarakat. Salah satu penyebab virus corona mudah menyebar di Indonesia adalah karena Indonesia merupakan negara dengan sektor pariwisata yang cukup luas sehingga dengan banyaknya turis berdatangan itu akan sangat mempengaruhi peningkatan dari virus covid-19. Bentuk nyata yang dapat dilihat dari dampak pandemi ini banyak pabrik, toko, dan UMKM lainnya yang terpaksa menutup usahanya serta terancam bangkrut, juga ternyadinya PHK, banyak karyawan yang dirumahkan.

Ekonomi merupakan faktor yang terpenting dalam kehidupan manusia. Kebutuhan ekonomi erat kaitannya dalam kehidupan sehari-sehari (Yamali \& Putri, 2020). Manusia untuk memenuhi kebutuhannya seperti makan, minum, pakaian, tempat tinggal dan lainlain memerlukan suatu ekonomi yang kuat. Oleh karena itu negara mengatur kebijakan mengenai perekonomian dan faktor untuk menjamin ekonomi masyarakat, dengan cara bermunculan berbagai lembaga untuk mengatasi permasalahan perekonomian Indonesia, salah satunya adalah lembaga keuangan non bank seperti pegadaian yang memberikan pelayanan kepada masyarakat yang membutuhkan dana untuk membantu pembangunan ekonominya, dengan cara menggadaikan sebagian hartanya guna untuk bertahan hidup pada saat pandemi covid-19.

PT Pegadaian bertujuan untuk membantu dan melayani kebutuhan masyarakat bukan hanya untuk pengusaha berskala kecil dan menengah tetapi juga untuk kebutuhan konsumsi rumah tangga. PT Pegadaian termasuk perusahaan jasa dimana sebagai penyedia jasa harus mampu meyakinkan konsumen atau calon konsumen bahwa pelayanan serta 
produk yang ditawarkan memiliki kepuasan tersendiri. Hal tersebut harus dilakukan karena konsumen akan menilai pelayanan yang diberikan oleh suatu perusahaan dengan membandingkan pelayanan yang diterima dengan pelayanan yang diharapkannya dari perusahaan satu dengan perusahaan lain yang sejenis.

Perusahaan dituntut untuk mengetahui kebutuhan dan keinginan para konsumen yang setiap saat berubah dengan cepat sesuai dengan apa yang diharapkan atau di inginkan oleh para konsumen guna untuk memenuhi kepuasan para konsumen, Pada awalnya konsumen hanya membeli sebuah produk kemudian konsumen baru akan menyadari apakah produk tersebut sesuai dengan yang diinginkan konsumen ataupun tidak (Yusuf, 2017). Pengaruh pandemi covid-19 ini menyebabkan perubahan pada sistem pelayanan yang dilakukan oleh PT Pegadain Outlet Kedaton yang mengharuskan perusahaan dan seluruh karyawan mengikuti protokol kesehatan yang sudah ditetapkan. Perusahan dan karyawan dalam melakukan pencegahan pandemi disarankan yaitu menjaga jarak bersama konsumen minimal 1 meter, memakai masker, menerapkan jam operasional perusahaan yang dikurangi, dibatasasinya ketentuan konsumen didalam ruangan yaitu 50\% dari kapasitas ruangan, menyediakan fasilitas untuk mencuci tangan atau menyediakan cairan pembersih yang memadai dalam jumlah yang cukup dan mudah dijangkau di area pintu keluar masuk gedung, dan sistem pembayaran perpanjangan gadai tidak hanya dapat dilakukan di kantor atau PT Pegadaian Outlet Kedaton tetapi dapat dilakukannya secara online melalui online juga dapat dilakukan di gerai indomaret guna untuk mempermudah konsumen mendapatkan pembayaran yang praktis dan instan.

\section{KAJIAN LITERATUR Kualitas Pelayanan}

Kualitas mempunyai arti yaitu suatu kondisi yang selalu berubah, sedangkan pelayanan ialah jasa yang diberikan oleh pemilik jasa (perusahaan) berupa kemudahan, kecepatan, hubungan, kemampuan, dan keramahan yang diselesaikan dengan sikap dan sifat pelayanan yang berdampak untuk memberikan kepuasan pelanggan. Maka kualitas pelayanan adalah semua bentuk kegiatan yang dilakukan perusahaan untuk memenuhi harapan pelanggan. (Mahsyar \& Surapati, 2020).

Farooq et al., (2018) mengemukakan kualitas layanan merupakan salah satu faktor penentu keberhasilan dalam industri jasa saat ini, terutama jika dianggap sebagai salah satu faktor pembeda. Karim (2020) menyatakan kualitas pelayanan yaitu perbedaan antara harapan konsumen tentang layanan yang diberikan dan dirasakan. Pada masa sekarang persaingan yang berhubungan dengan kualitas pelayanan adalah senjata untuk menopang dan bersaing dengan kompetitor. Khususnya dibidang jasa kualitas pelayanan sangat penting karena memberikan tingkat kepuasan konsumen yang tinggi, sehingga menjadi sarana yang lebih besar untuk memperoleh keunggulan bersaing.

\section{Kepuasan Konsumen}

Menurut Kotler dan Keller (2016) kepuasan konsumen adalah suatu perasaan senang ataupun kecewa seseorang yang diakibatkan karena membandingkan antara kinerja yang dipersepsikan suatu produk terhadap ekspetasi sesorang, apabila hasil atau kinerja yang diperoleh tidak sesuai dengan harapan seorang konsumen maka konsumen akan merasa tidak puas, begitu juga sebaliknya apabila sesuai atau melebihi harapan, maka konsumen akan merasa puas.

Menurut Famiyeh et al., (2018) berpendapat bahwa kepuasan konsumen secara umum didefinisikan sebagai perasaan atau penilaian konsumen terhadap produk atau jasa setelah konsumen menggunakannya. 
Merujuk pada uraian diatas, untuk mengetahui apakah pengaruh kualitas pelayanan terhadap kepuasan konsumen saat pandemi covid-19. Maka peneliti menerangkan hipotesis berikut:

H1 Bukti Fisik berpengaruh positif dan signifikan terhadap kepuasan konsumen di PT Pegadaian Outlet Kedaton di Bandar Lampung

H2 Empati berpengaruh positif dan signifikan terhadap kepuasan konsumen di PT Pegadaian Outlet Kedaton di Bandar Lampung

H3 Keandalan berpengaruh positif dan signifikan terhadap kepuasan konsumen di PT Pegadaian Outlet Kedaton di Bandar Lampung

H4 Ketanggapan berpengaruh positif dan signifikan terhadap kepuasan konsumen di PT Pegadaian Outlet Kedaton di Bandar Lampung

H5 Jaminan berpengaruh positif dan signifikan terhadap kepuasan konsumen di PT Pegadaian Outlet Kedaton di Bandar Lampung

\section{METODE PENELITIAN}

Penelitian yang digunakan dalam penelitian ini merupakan jenis penelitian kuantitatif, dimana penelitian ini untuk mengetahui hubungan lalu pengaruh antara variabel bebas dan variabel terikat. Pengambilan data dilakukan dengan metode kuisioner terhadap 100 responden yang telah berkunjung serta melakukan transaksi di PT. Pegadaian Outlet Kedaton saat pandemi covid-19. Pengujian hipotesis dilakukan dengan uji secara parsial (uji t), uji secara simultan (uji f), dan analisis koefisien determinasi $\left(\mathrm{R}^{2}\right.$ ). Responden diminta untuk menilai tingkat kepuasan berdasarkan persepsinya terhadap setiap item pertanyaannya, yang diukur menggunakan skala likert 5 poin dengan skor maksimum 5 dan minimum 1, mulai dari sangat tidak setuju (1) sampai dengan sangat setuju (5). Analisis alat bantu dalam penelitian ini menggunakan IBM SPSS Statistics 22 (Priyanto, 2014).

Demografi responden yang diukur pada penelitian ini meliputi jenis kelamin, usia, pekerjaan, penghasilan perbulan, dan berkunjung ke PT Pegadaian Outlet Kedaton. Penelitian ini didominasi oleh perempuan 58\%. Untuk usia responden didominasi rentang usia 26-35 tahun sebesar 33\%. Untuk pekerjaan didominasi oleh pegawai swasta atau wiraswata dengan penghasilan perbulan didominasi Rp $501.000-2.000 .000$,- sebesar $32 \%$. Pada penelitian ini responden pernah berkunjung ke PT Pegadaian Outlet Kedaton serta melakukan transaksi sebesar $100 \%$.

\section{HASIL PENELITIAN DAN PEMBAHASAN Uji Validitas dan Reliabilitas}

Uji validitas dilakukan untuk mengetahui sah atau valid tidaknya suatu kuisioner. Pengujian validitas pada penelitian ini dilakukan dengan ketentuan nilai Kaiser Meyer Oklin (KMO), nilai anti-image correlation, dan factor loading $\geq 0,5$. Tabel 1 . menunjukkan bahwa nilai Kaiser Meyer Olkin (KMO), anti image, dan factor loading dari semua indikator yaitu Bukti Fisik (X1), Empati (X2), Keandalan (X3), Keandalan (X4), Jaminan (X5) dan Kepuasan Konsumen (Y) menunjukkan nilai > 0,5 valid, yang berarti bahwa semua indikator yang digunakan dalam penelitian adalah valid dan bisa diproses untuk langkah selanjutnya. Tabel 2 menunjukkan bahwa nilai Cronbach Alpha lebih besar dari 0,6 dan nilai Cronbach's Alpha If Item Deleted tidak melebihi nilai Cronbach Alpha. maka dapat disimpulkan bahwa keseluruhan variabel yang digunakan dalam penelitian ini reliabel. 
Tabel 1. Hasil Uji Validitas

\begin{tabular}{|c|c|c|c|c|c|}
\hline Variabel & Item & $\begin{array}{c}\text { KMO } \\
\text { Kaiser } \\
\text { Meyer Oklin }\end{array}$ & $\begin{array}{c}\text { Anti } \\
\text { Image }\end{array}$ & $\begin{array}{c}\text { Factor } \\
\text { Loading }\end{array}$ & Keterangan \\
\hline \multirow{3}{*}{$\begin{array}{c}\text { Bukti Fisik } \\
\text { (Tangible) } \mathrm{X}_{1}\end{array}$} & $\mathrm{X} 1 \_1$ & \multirow{3}{*}{0,688} & 0.715 & 0.795 & Valid \\
\hline & X1_2 & & 0,673 & 0,827 & Valid \\
\hline & X1_3 & & 0,679 & 0,821 & Valid \\
\hline \multirow{3}{*}{$\begin{array}{l}\text { Empati (Emphaty) } \\
\qquad \mathrm{X}_{2}\end{array}$} & X2_1 & \multirow{3}{*}{0,691} & 0,690 & 0,817 & Valid \\
\hline & X2_2 & & 0,680 & 0,825 & Valid \\
\hline & X2_3 & & 0,704 & 0,807 & Valid \\
\hline \multirow{3}{*}{$\begin{array}{c}\text { Keandalan } \\
\text { (Reliability) } \mathrm{X}_{3}\end{array}$} & X3_1 & \multirow{3}{*}{0,682} & 0,707 & 0,799 & Valid \\
\hline & X3_2 & & 0,699 & 0,804 & Valid \\
\hline & X3_3 & & 0,649 & 0,849 & Valid \\
\hline \multirow{3}{*}{$\begin{array}{c}\text { Ketanggapan } \\
\text { (Responsiveness) } \\
\mathrm{X}_{4}\end{array}$} & X4_1 & \multirow{3}{*}{0,697} & 0,676 & 0,854 & Valid \\
\hline & X4_2 & & 0,677 & 0,853 & Valid \\
\hline & X4_3 & & 0,752 & 0,805 & Valid \\
\hline \multirow{3}{*}{$\begin{array}{c}\text { Jaminan } \\
\text { (Assurance) } \mathrm{X}_{5}\end{array}$} & X5_1 & \multirow{3}{*}{0,706} & 0,731 & 0,827 & Valid \\
\hline & X5_2 & & 0,705 & 0,843 & Valid \\
\hline & X5_3 & & 0,686 & 0,856 & Valid \\
\hline \multirow{5}{*}{$\begin{array}{c}\text { Kepuasan } \\
\text { Konsumen (Y) }\end{array}$} & Y1_1 & \multirow{5}{*}{0,748} & 0,712 & 0,778 & Valid \\
\hline & Y1_2 & & 0,795 & 0,753 & Valid \\
\hline & Y1_3 & & 0,760 & 0,716 & Valid \\
\hline & Y1_4 & & 0,726 & 0,736 & Valid \\
\hline & Y1_5 & & 0,759 & 0,706 & Valid \\
\hline
\end{tabular}

Tabel 2. Hasil Uji Reliabilitas

\begin{tabular}{|c|c|c|c|c|}
\hline Variabel & Item & $\begin{array}{l}\text { Cronbach } \\
\text { Alpha }\end{array}$ & $\begin{array}{c}\text { Cronbach } \\
\text { Alpha If Item } \\
\text { Deleted }\end{array}$ & Keterangan \\
\hline \multirow{3}{*}{$\begin{array}{l}\text { Bukti Fisik } \\
\text { (Tangible) } \mathrm{X}_{1}\end{array}$} & X1_1 & \multirow{3}{*}{0,745} & 0,691 & Reliabel \\
\hline & $\mathrm{X} 1=2$ & & 0,640 & Reliabel \\
\hline & $\mathrm{X} 1 \_3$ & & 0,651 & Reliabel \\
\hline \multirow{3}{*}{$\begin{array}{c}\text { Empati } \\
\text { (Emphaty) } \mathrm{X}_{2}\end{array}$} & $\mathrm{X} 2$ & \multirow{3}{*}{0,748} & 0,663 & Reliabel \\
\hline & $\mathrm{X} 2-2$ & & 0,651 & Reliabel \\
\hline & $\mathrm{X} 2 \_3$ & & 0,681 & Reliabel \\
\hline \multirow{3}{*}{$\begin{array}{c}\text { Keandalan } \\
\text { (Reliability) } X_{3}\end{array}$} & X3_1 & \multirow{3}{*}{0,749} & 0,696 & Reliabel \\
\hline & X3_2 & & 0,690 & Reliabel \\
\hline & $\mathrm{X} 3{ }_{3}$ & & 0,609 & Reliabel \\
\hline \multirow{3}{*}{$\begin{array}{c}\text { Ketanggapan } \\
\text { (Responsiveness) } \\
\mathrm{X}_{4}\end{array}$} & X4_1 & \multirow{3}{*}{0,786} & 0,684 & Reliabel \\
\hline & X4_2 & & 0,685 & Reliabel \\
\hline & X4_3 & & 0,759 & Reliabel \\
\hline \multirow{3}{*}{$\begin{array}{c}\text { Jaminan } \\
(\text { Assurance }) \\
\mathrm{X}_{5}\end{array}$} & X5_1 & \multirow{3}{*}{0,793} & 0,744 & Reliabel \\
\hline & X5_2 & & 0,717 & Reliabel \\
\hline & X5_3 & & 0,691 & Reliabel \\
\hline \multirow{5}{*}{$\begin{array}{c}\text { Kepuasan } \\
\text { Konsumen (Y) }\end{array}$} & Y1_1 & \multirow{5}{*}{0,790} & 0,734 & Reliabel \\
\hline & Y1_2 & & 0,744 & Reliabel \\
\hline & Y1_3 & & 0,758 & Reliabel \\
\hline & Y1_4 & & 0,753 & Reliabel \\
\hline & Y1_5 & & 0,763 & Reliabel \\
\hline
\end{tabular}




\section{Uji Regresi}

Tabel 3 menunjukan bahwa nilai konstanta sebesar 4,764 nilai variabel Bukti Fisik (X1) sebesar 0,168 Empati (X2) sebesar 0,188, Keandalan (X3) sebesar 0,221, Ketanggapan (X4) sebesar 0,208, dan Jaminan (X5) sebesar 0,207. Berdasarkan nilai tersebut persamaan regresi linier berganda dapat disusun sebagai berikut:

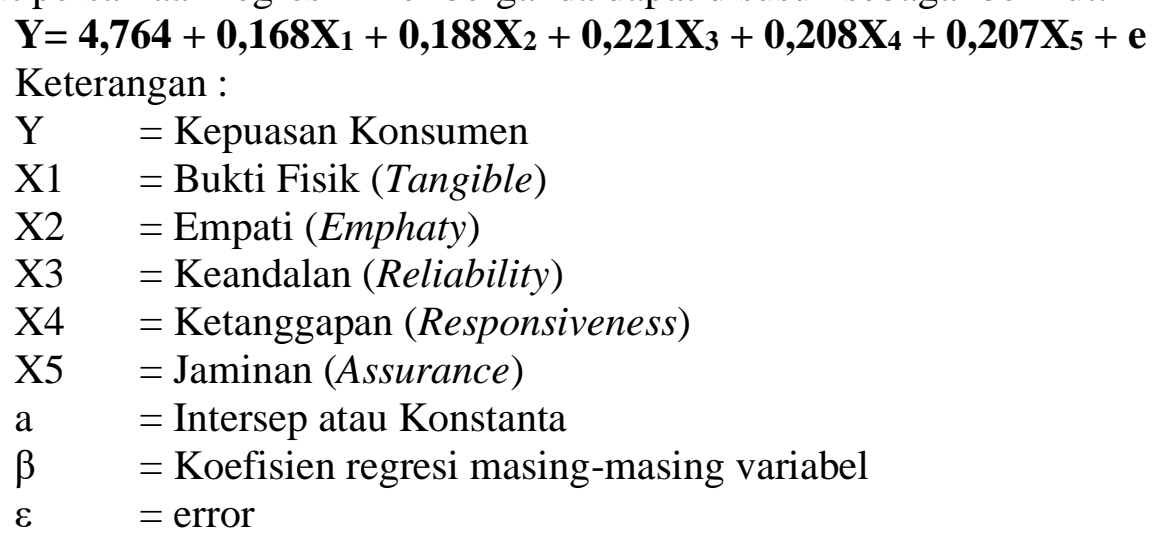

Berdasarkan hasil diatas disimpulkan bahwa $\mathrm{X} 1, \mathrm{X} 2, \mathrm{X} 3, \mathrm{X} 4, \mathrm{X} 5$ berpengaruh positif, sehingga dapat dilakukan ada pengaruh antara variabel kualitas pelayanan meliputi bukti fisik, empati, keandalan, ketanggapan, dan jaminan terhadap kepuasan konsumen.

Tabel 3. Hasil Uji Regresi Linier Berganda

\begin{tabular}{llrrrc}
\hline \multicolumn{1}{c}{ Model } & B & Std. Error & Beta & t & Sig. \\
\hline (Constant) & 4,764 & 1,179 & & 4,039 & 0,000 \\
X1 & 0,258 & 0,108 & 0,168 & 2,378 & 0,019 \\
X2 & 0,251 & 0,115 & 0,188 & 2,178 & 0,032 \\
X3 & 0,296 & 0,141 & 0,221 & 2,103 & 0,038 \\
X4 & 0,280 & 0,136 & 0,208 & 2,066 & 0,042 \\
X5 & 0,282 & 0,124 & 0,207 & 2,273 & 0,025 \\
\hline \multicolumn{7}{r}{ a. Dependent Variable: Kepuasan Konsumen } & &
\end{tabular}

Berdasarkan hasil uji hipotesis pada Tabel 4, dapat diketahui sebagai berikut:

a. Bukti Fisik mempunyai nilai $\mathrm{t}$ hitung $=2,378>\mathrm{t}$ tabel $=1,9855$ dengan tingkat signifikan sebesar 0,019 < 0,05, maka H0 ditolak dan H1 diterima. Sehingga Bukti Fisik berpengaruh terhadap Kepuasan Konsumen.

a. Berdasarkan tabel 4, dapat diketahui bahwa Empati mempunyai t hitung = 2,178 > $\mathrm{t}$ tabel $=1,9855$ dengan tingkat signifikan sebesar 0,032 <0,05, maka H0 ditolak dan H2 diterima. Sehingga Empati berpengaruh terhadap Kepuasan Konsumen.

b. Berdasarkan tabel 4, dapat diketahui bahwa Keandalan mempunyai t hitung = $2,103>\mathrm{t}$ tabel $=1,9855$ dengan tingkat signifikan sebesar 0,038 $<0,05$, maka $\mathrm{H} 0$ ditolak dan H3 diterima. Sehingga Keandalan berpengaruh terhadap Kepuasan Konsumen.

c. Berdasarkan tabel 4, dapat diketahui bahwa Ketanggapan mempunyai t hitung $=$ 2,066 $>\mathrm{t}$ tabel $=1,9855$ dengan tingkat signifikan sebesar 0,042 <0,05, maka H0 ditolak dan H4 diterima. Sehingga Ketanggapan berpengaruh terhadap Kepuasan Konsumen.

d. Berdasarkan tabel 4, dapat diketahui bahwa Jaminan mempunyai t hitung $=2,273>$ $\mathrm{t}$ tabel $=1,9855$ dengan tingkat signifikan sebesar $0,025<0,05$, maka $\mathrm{H} 0$ ditolak dan H5 diterima. Sehingga Jaminan berpengaruh terhadap Kepuasan Konsumen. Tabel dan gambar diletakkan di tengah halaman. 
Tabel 4. Hasil Uji Hipotesis Secara Parsial (Uji t)

\begin{tabular}{|c|c|c|c|c|}
\hline Variabel & t hitung & $t$ tabel & Sig & Keterangan \\
\hline $\begin{array}{l}\text { H1 : Bukti Fisik berpengaruh signifikan } \\
\text { terhadap kepuasan Konsumen di outlet } \\
\text { Pegadaian Kedaton. }\end{array}$ & 2.378 & 1.985 & 0.019 & H1 diterima \\
\hline $\begin{array}{l}\mathrm{H} 2 \text { : Empati berpengaruh signifikan } \\
\text { terhadap kepuasan Konsumen di outlet } \\
\text { Pegadaian Kedaton. }\end{array}$ & 2.178 & 1.985 & 0.032 & $\mathrm{H} 2$ diterima \\
\hline $\begin{array}{l}\text { H3 : Keandalan berpengaruh signifikan } \\
\text { terhadap kepuasan Konsumen di outlet } \\
\text { Pegadaian Kedaton }\end{array}$ & 2.103 & 1.985 & 0.038 & H3 diterima \\
\hline $\begin{array}{l}\text { H4 : Ketanggapan berpengaruh } \\
\text { signifikan terhadap kepuasan Konsumen } \\
\text { di outlet Pegadaian Kedaton }\end{array}$ & 2.066 & 1.985 & 0.042 & H4 diterima \\
\hline $\begin{array}{l}\text { H5 : Jaminan berpengaruh signifikan } \\
\text { terhadap kepuasan Konsumen di outlet } \\
\text { Pegadaian Kedaton }\end{array}$ & 2.273 & 1.985 & 0.025 & H5 diterima \\
\hline
\end{tabular}

Berdasarkan Tabel 5 hasil uji f, menunjukan nilai Fhitung 50,948 dan tingkat signifikan untuk Bukti Fisik, Empati, Keandalan, Ketanggapan dan Jaminan, adalah 0,000 atau kurang dari 0,05. Maka model regresi Bukti Fisik, Empati, Keandalan, Ketanggapan dan Jaminan, secara simultan berpengaruh terhadap Kepuasan Konsumen.

Tabel 5. Hasil Uji F

\begin{tabular}{lrrrrc}
\hline \multicolumn{1}{c}{ Model } & $\begin{array}{c}\text { Sum of } \\
\text { Squares }\end{array}$ & df & $\begin{array}{c}\text { Mean } \\
\text { Square }\end{array}$ & F & Sig. \\
\hline Regression & 353,220 & 5 & 70,644 & 50,948 & $0,000^{\mathrm{b}}$ \\
Residual & 130,340 & 94 & 1,387 & & \\
Total & 483,560 & 99 & & & \\
\hline
\end{tabular}

a. Dependent Variable: kepuasan konsumen

b. Predictors: (Constant), jaminan, bukti fisik, empati, ketanggapan, keandalan

Berdasarkan Tabel 6 hasil uji koefisien determinasi diatas, besarnya R Square adalah 0,730. Hasil perhitungan statistic ini berarti kemampuan variabel independen Bukti Fisik (X1), Empati (X2), Keandalan (X3) dan Ketanggapan (X4) dalam menerangkan dan mempengaruhi variabel dependen Kepuasan Konsumen (Y) sebesar 73\% sisanya 27\% dijelaskan oleh variabel lain diluar model regresi yang dianalisis.

Tabel 6. Hasil Uji Koefisien Determinasi $\left(\mathbf{R}^{2}\right)$

\begin{tabular}{|c|c|c|c|c|}
\hline Model & $\mathbf{R}$ & $\begin{array}{c}\mathbf{R} \\
\text { Square }\end{array}$ & $\begin{array}{l}\text { Adjusted R } \\
\text { Square }\end{array}$ & $\begin{array}{c}\text { Std. Error of the } \\
\text { Estimate }\end{array}$ \\
\hline 1 & $0,855^{\mathrm{a}}$ & 0,730 & 0,716 & 1,178 \\
\hline
\end{tabular}

\section{SIMPULAN}

Berdasarkan hasil penelitian yang telah dilakukan, dapat disimpulkan bahwa hipotesis awal yang menyatakan terdapat pengaruh kualitas pelayanan berpengaruh positif secara signifikan terhadap kepuasan konsumen pada outlet Pegadaian Kedaton di Bandar Lampung pada masa pandemi covid-19, diterima. Hal ini berdasarkan pada: ariabel Bukti Fisik (tangible) (X1) berpengaruh positif dan signifikan terhadap Kepuasan Konsumen 
(Y). Variabel Empati (emphaty) (X2) berpengaruh positif dan signifikan terhadap Kepuasan Konsumen (Y). Variabel Keandalan (reliability) (X3) berpengaruh positif dan signifikan terhadap Kepuasan Konsumen (Y). Variabel Ketanggapan (responsiveness) (X4) berpengaruh positif dan signifikan terhadap Kepuasan Konsumen (Y). Variabel Jaminan (assurance) (X5) berpengaruh positif dan signifikan terhadap Kepuasan Konsumen (Y).

\section{SARAN}

Berdasarkan hasil penelitian yang telah dilakukan, maka peneliti bermaksud memberikan saran dan masukan yang dapat dijadikan pertimbangan kepada perusahaan. Adapun saran yang peneliti berikan sebagai berikut :

Outlet Pegadaian Kedaton di Bandar Lampung sebaiknya meningkatkan kualitas pelayanan dari sisi melayani konsumen dengan cara menerapkan 3S (senyum, sapa, dan salam) seperti menyapa konsumen yang datang ke PT Pegadaian Outlet Kedaton, menanyakan keluhan yang ada pada konsumen, memberikan solusi yang tepat terhadap permasalahan yang dikeluhkan konsumen serta membantu konsumen dalam mencari solusi untuk memecahkan masalah yang dihadapi konsumen agar dapat membantu meringankan masalah yang sedang konsumen alami sehingga terciptanya pelayanan yang nyaman serta menarik minat konsumen untuk datang. Apabila konsumen sudah memiliki kesan yang baik maka konsumen akan selalu datang berkunjung dan juga merekomendasikannya kepada orang lain.

Outlet Pegadaian Kedaton di Bandar Lampung sebaiknya memperhatikan dimensi bukti fisik (tangible) karena dimensi ini merupakan variabel terendah, hal ini dikarenakan belum dapat dioptimalkan oleh outlet Pegadaian Kedaton. Perusahaan seharusnya perlu menata ulang tata letak tempat duduk, hiasan dinding, menyediakan tambahan kursi untuk konsumen yang menunggu diluar gedung, merubah sebagian interior didalam kantor agar lebih bagus dan menarik, dan mengganti peralatan yang rusak dengan peralatan dengan kualitas yang terbaik dan modern, selain penampilan interior kantor, penampiran eksterior juga harus di perhatikan PT Pegadaian Outlet Kedaton seperti menyediakan lahan parkir yang luas untuk kemudahan nasabah dalam memarkir kendaraannya serta menjamin keamanan kendaraan nasabah dengan begitu para nasabah tidak perlu khawatir dengan kendaraannya. Penampilan karyawan yang bersih dan rapi juga sangat mempengaruhi kepuasan konsumen, oleh karena itu karyawan harus mempertahankan penampilannya dengan sesuai protokol kesehatan yaitu memakai masker.

Outlet Pegadaian Kedaton di Bandar Lampung sebaiknya meningkatkan variabel empati (emphaty) dimana perusahaan mampu memahami masalah para konsumen dengan kata lain ikut turut merasakan perasaan orang lain dan serta memberikan perhatian individu kepada para konsumen. Outlet Pegadaian Kedaton di Bandar Lampung sebaiknya mempertahankan variabel keandalan (reliability) karena variabel tertinggi, untuk mempertahankan variabel ini dalam perusahaan yaitu dengan cara perusahaan mampu memaksimalkan layanan digital sehingga transaksi nasabah dapat berjalan dengan mudah.

Outlet Pegadaian Kedaton di Bandar Lampung sebaiknya meningkatkan variabel ketanggapan (responsiveness) yaitu kesadaran karyawan dalam bertindak cepat tanggap untuk membantu dan menyelesaikan keluhan konsumen dengan tepat waktu, berbicara menggunakan bahasa yang mudah dimengerti dan dipahami, dan adanya tambahan pegawai untuk penjaga agunan agar konsumen tidak lama menunggu dalam transaksi penebusan barang. Outlet Pegadaian Kedaton di Bandar Lampung sebaiknya meningkatkan variabel jaminan (assurance) dengan karyawan dapat menumbuhkan sikap 
sopan santun dan ramah saat memberikan pelayanan sehingga menimbulkan suasana aman ketika melakukan transaksi di pegadaian outlet kedaton.

\section{DAFTAR PUSTAKA}

Famiyeh, S., Asante-Darko, D. and Kwarteng, A. (2018), "Service quality, customer satisfaction, and loyalty in the banking sector: The moderating role of organizational culture", International Journal of Quality \& Reliability Management, Vol. 35 No. 8, pp. 1546-1567.

Farooq, M. S., Salam, M., Fayolle, A., Jaafar, N., \& Ayupp, K. (2018). Impact of service quality on customer satisfaction in Malaysia airlines: A PLS-SEM approach. Journal of Air Transport Management, 67(September 2017), 169-180.

Karim, R. Al. (2020). Influence of Service Quality on Customer Satisfaction and Customer Loyalty in the Private Banking Sector of Bangladesh: A PLS Approach. Journal of Marketing and Information Systems, 1(3), 8-17.

Kotler, Philip \& Keller, Kevin Lane.(2016). Marketing Managemen, 15th Edition, Pearson Education,Inc.

Lasander, C. (2013). Citra merek, kualitas produk, dan promosi pengaruhnya terhadap kepuasan konsumen pada makanan tradisional. Jurnal EMBA: Jurnal Riset Ekonomi, Manajemen, Bisnis dan Akuntansi, 1(3).

Mahsyar, S., \& Surapati, U. (2020). Effect of Service Quality and Product Quality on Customer. International Journal of Economics, Business and Accounting Research (IJEBAR), 4(1), 204-211.

Priyanto, Dwi . 2014. SPSS 22 : pengolahan data terpraktis, Yogyakarta : Andi Offset

Yamali, F. R., \& Putri, R. N. (2020). Dampak Covid-19 Terhadap Ekonomi Indonesia. Ekonomis: Journal of Economics and Business, 4(2), 384-388.

Yusuf, I. M. (2017). Pengaruh harga dan suasana cafe terhadap kepuasan konsumen pada cafe Cofindo Bandung (Doctoral dissertation, Fakultas Ekonomi dan Bisnis Unpas Bandung). 